\title{
Papers
}

\section{Asset managers: What is the duty of care?}

Received: 24th February, 2003

\section{Robin Ellison}

is a partner in the pensions team at Pinsents, one of the largest pensions law teams in Europe. He acts for a number of blue chip clients and government departments, and is a trustee of several pension schemes. He is the author of a four-volume legal text, 'Pensions Law and Practice' (Sweet and Maxwell) and editor of 'Pensions Benefits Law Reports'. He is also the Chairman of Pendragon, which provides the industry's electronic information service Perspective, and a member of the Council of the National Association of Pension Funds. He is the Editor of Pensions.

\begin{abstract}
This paper examines the liability of investment managers following the part-heard case of Unilever's pension fund $v$ Merrill Lynch at the end of 2001. It explores the contractual and tort exposure and the undetermined problem of how to measure and control investment risk exposures in compliance with a strict mandate.
\end{abstract}

Keywords: investments; investment managers; risk control; legal liability; investment contracts

\section{Introduction}

In October and November 2001, a High Court case in London hit the tabloid headlines. The tabloids concentrated on the various power jackets worn by two of the women most involved in the case, respectively the Chief Investment Officer of the Unilever fund, and the Chief Executive of the Merrill Lynch asset management team. The Unilever pension fund claimed it had lost, $130 \mathrm{~m}$ through the negligent investment management of their asset managers, in this case Merrill Lynch. ${ }^{1}$ The litigation sent shivers through both the pension fund movement and the asset management industry. Moreover, its impact was not limited to the UK; its influence has spread worldwide throughout the asset management sector, and led to a review of investment management agreements and the role of asset managers.
This note ignores the fashion elements which so fascinated the popular press. Instead it explores some of the legal and practical issues raised by that litigation, and discusses whether there are lessons to be learned by trustees generally and asset managers for their future conduct. In particular, it considers the core question raised by the litigation: what is the duty of care owed by an asset manager to its client? Finally, it considers a number of practical implications.

One of the curious features of the case was that, despite the significance of asset management to the UK and US economies, it was an original; there has been little reported litigation on the subject before this trial, either in the UK or even in the USA. The USA, whose constitution operates on the ready availability of litigation, has hardly any precedents for such a case and, 
considering the sums involved, and the losses that have often been incurred, it is strange that the courts have not been widely invoked in the past. There may be several reasons for this. First, the burden of proof may have been perceived to be high. The courts would have to have demonstrated a failure of process by an asset manager, and even discovery (production of documents) would be unlikely to show that. Secondly, there are time factors; by the time the litigation came to court the portfolio may be on an up. This

happened in the seminal pensions case in the USA of Bierworth $v$ Donovan (US) 680 F 2d 263 (2d Cir) cert denied; 459 US 1069 (1982). The US Department of Labor sued the trustees of the Grumman aircraft pension fund for buying shares in the parent company to help fend off an acquisition of the company by Lockheed, but by the time the case came to trial the share price had recovered sufficiently so that no loss could be demonstrated.

\section{Background}

In October 1999 the Unilever pension plan sued Mercury Asset Management, a British asset manager later acquired by the US firm Merrill Lynch, in the Queen's Bench Division of the High Court in London. It sought damages arising from Merrill Lynch's breach of contract, under an investment management agreement (IMA) made in November 1997. The IMA provided that the investment objective was 'to produce a return of 1 per cent p.a. in excess of the benchmark, net of fees, over periods since inception of the portfolio subject to a reasonable minimum period of three years. Note: In normal circumstances the return will be expected to be no more than 3 per cent below the benchmark in any period of 4 successive calendar quarters.'
The particulars of claim acknowledged that Merrill Lynch had not guaranteed that the downside tolerance would not be breached; but it alleged that Merrill's obligation was no more and no less than to exercise the highest standards of care and expertise in relation to the downside tolerance, as well as in relation to the target return.

In January 1997 Merrill Lynch had just over $£ 1$ bn to manage for Unilever; over the next five quarters the return was cumulatively 8.93 per cent below the benchmark (compared with the objective of 1 per cent over). It clearly breached the 3 per cent downside limit mentioned in the objectives. The main reason for the under-performance appeared to lie in the equity element of the portfolio, amounting to around $6600 \mathrm{~m}$. Moreover, in relation to that equity portfolio alone, the returns were even less impressive: for the period from April 1997 to March 1998 the return was 14.49 per cent below the benchmark, the FTSE All-Share Index.

The question at issue was: did Merrill Lynch fail to exercise the highest standards of care and expertise, or even reasonable care and expertise? The subsidiary, yet critical element, was whether Merrill had managed the portfolio with the objective of meeting the 1 per cent target while managing to contain the risk.

There was no doubt that the portfolio did not reflect that of a tracker fund. First, its strategic structure was very different. It was heavily into 'general industrials' (45 per cent of the portfolio, compared with 15 per cent of the FTSE index) and low in for example 'financials' (12 per cent of the portfolio, compared with 19 per cent of the FTSE index).

Secondly, it was alleged that there was undue stock concentration. Merrill Lynch had the $6600 \mathrm{~m}$ in 42 stocks, of which four stocks represented only $\mathcal{K}^{5} \mathrm{~m}$ of the 
portfolio. Around 75 per cent of the equity fund was in 20 stocks.

The defence was not published; but in Merrill's favour was the fact that the stock market itself was unbalanced. Nearly 45 per cent of the stock market at one time was represented by only three stocks (BP-Amoco, Vodaphone and GlaxoSmithKline). But it was evident that the portfolio was heavily into building, property and construction stocks. Using the 'load ratio' analysis (the load ratio is the ratio between the proportion of the UK Equity Fund represented by the holding in the company as against the proportion of the FTSE All-Share Index represented by that company; a load ratio of 100 represented an identical weighting in the fund and in the index), the top ten holdings represented 16 per cent of the fund as against 0.46 per cent of the index; and the top 20 holdings represented 46 per cent of the fund as against 2 per cent of the index.

Because of these weightings, the Merrill Lynch equity fund performed poorly in comparison with other peer investment managers. For example, in a comparison with 1,624 funds, Merrill Lynch's fund was in the 100th percentile, ie bottom of the list. And in comparison with aggressive funds (20 funds with a target to achieve 2 per cent over the FTSE All-Share index) they were also bottom of the list. There were 94 funds with a specified target of 1 per cent over the Index, and Merrills were also bottom of this list.

The claim form sought damages of f110m, that is the amount that a reasonably competent fund manager would have achieved if acting in accordance with the IMA and the investment guidelines. This was based on achieving the Index return, rather than the 1 per cent over the Index. The claim form also sought unspecified extra amounts compounded on the loss incurred by the lower returns received on the lower capital value now invested by the fund by other managers. And there was, of course, a claim for interest.

The case in the end was discontinued by Unilever's pension fund trustees; Merrill Lynch reportedly paid f70m in $^{2}$ settlement of the claim. The judge later criticised both sides for failing to have resorted to mediation or other form of alternative dispute resolution; the case had lasted 28 days in court, and involved very substantial costs. Neither party's reputation was enhanced by the process. And for legal advisers, trustees of private trust funds and asset managers, the resolution of the dispute was deeply unsatisfactory. There was no judgment by the High Court, or judgment by the Court of Appeal, or judgment by the House of Lords that could be used for guidance in the future in establishing future behaviour. Mr Paul Myners, who had earlier that year delivered his UK Treasury-commissioned report on pension fund investment policy, ${ }^{2}$ commented in a speech to the UK Society of Pension Consultants in November 2001 that the process itself, regardless of its resolution, would have the unwelcome effect of moving asset managers to safety, and thereby to lower returns and higher costs for investors.

The case raised a number of issues, which have yet to be resolved, and which some observers thought best not discussed in the first place. It is these issues which are the subject of this paper.

\section{Contractual liability}

It is a rare investment management agreement that guarantees a rate of return; such promises are usually only made in fixed coupon bonds issued by governments or corporations. Investment 
managers, however, frequently agree to objectives (benchmarks) using for want of any better phrase 'their best endeavours'. The Unilever/MAM agreement was no different; the core clauses provided that:

'Appointment of investment manager: In carrying out its duties and fulfilling its obligations under this Agreement, the Investment Manager shall act in good faith and shall exercise the highest standards of care, expertise and fidelity appropriate thereto... In carrying out its duties and fulfilling its obligations under this Agreement, the Investment Manager shall at all times comply with... the terms of this Agreement including the specific restrictions set out in this Investment Guidelines and the Annexures to this Agreement...

Investment objectives: The Investment Manager's investment objective for the Client shall be to achieve a return on the Assets in accordance with the Investment Guidelines.'

A similar, but rather different phraseology is used in the UK industry standard agreement issued by the Fund Managers Association: ${ }^{3}$

'Investment discretion

(a) The Manager will manage the Fund within the investment objectives and any restrictions stated in item 2 of the Schedule and will act in good faith and with due diligence. Subject to such objectives and restrictions, the Manager normally acting as agent will have complete discretion for the account of the Customer (and without prior reference to the Customer) to buy, sell, retain, exchange or otherwise deal in investments and other assets. make deposits, subscribe to issues and offers for sale and accept placings, underwritings and sub-underwritings of any investments, effect transactions on any markets, take all day to day decisions and otherwise act as the judges appropriate in relation to the management of the Fund, but always subject to the overriding principles of suitability and Best Execution.

Liability of Manager

(a) The Manager accepts responsibility for loss to the Customer to the extent that such loss is due to the negligence, wilful default or fraud of itself or any delegates appointed pursuant to paragraph 6(a) above or that of its or their employees. The Manager also accepts liability for any Custodian which is an Associate.

(b) The Manager will not otherwise be liable for any loss to the Customer.

(c) No warranty is given by the Manager as to the performance or profitability of the Fund or any part of it.'

As mentioned the investment guidelines in Unilever set an objective of 1 per cent above the benchmark (net of fees) since inception of the portfolio subject to a reasonable minimum time of three years with a note adding that in normal circumstances the return would be expected to be no more than 3 per cent below the benchmark in any period of four successive quarters. The objective of the clients and the managers had clearly failed; the question at issue was whether there had also been a breach of the contract.

Where an asset manager breaches the terms of the contract, damages may clearly be payable if a loss occurs as a consequence. For example, it is not uncommon for certain restrictions on assets to be overlooked. Many IMAs have constraints on purchase of the sponsor company's own shares, or on investments in competing companies, or on ethical or social grounds. Breach of these formal constraints is a breach of the contract. These are clear almost objective tests, with little room for disagreement.

Much more difficult, however, are subjective breaches, such as the one 
arising in Unilever. The contract requires the highest standards of care and expertise in carrying out the investment duties and the question was whether a failure to observe the benchmark by such a significant margin involved a breach of that contract. The danger in such a claim is that any major failure to reach the benchmark raises a suspicion of res ipsa loquitur (the thing speaks for itself): the mere failure indicates a breach of the duty of care.

It was this indirect contractual claim, ie that the contract required a duty of care, that caused such debate in the industry, and since it relies on the concepts involved in tort, in the commissioning of a civil wrong, and specifically the civil wrong of negligence, it seems more helpful to continue the discussion under that heading.

\section{The duty of care}

It was the fact that the claim in Unilever was in the end based on an allegation of negligence in the performance of the contract, rather than a direct breach of the contract, that caused such consternation in the market. A simple contractual claim, perhaps based on a special arrangement in the terms, and which was not reflected elsewhere in common agreements, was one thing; a general claim for negligence raised much wider issues. Unilever has consistently argued $^{1}$ that there were special terms; while there may have been, they were not pleaded in the claim before the court. The question that lies at the heart of the dispute, and of any future potential disputes between investing trustees and underperforming asset managers is: is there a duty of care? And if so, what is the duty of care? And what is its standard?

That there is a duty of care seems self-evident. There is no automatic duty in any relationship, whether contractual or not, but where a customer relies so much on the expertise, skills and integrity of an asset manager, who invariably holds out as being in possession of these skills and qualities, the consensus seems to be incontestably that there is a duty of care to manage the investments as a reasonable manager would. In Unilever there was a contractual obligation to exercise not merely reasonable skills, but the highest duty of care. Distinguishing between the two is not always easy.

An adviser is liable for acts of negligence where there is a duty of care, a breach of that duty, and reasonably foreseeable loss. That duty can arise from a contractual relationship or in tort, provided it is foreseeable that the negligence will cause loss and there is reasonable proximity.

The standard of care expected is that usually associated with the efficient discharge of investment management services; it may be higher where fees are higher than normal, or where the asset manager suggests he has special expertise in a particular area of activity. The breach is a question of fact and the losses must flow directly from the breach and must not be too remote and must be reasonably foreseeable.

The complaint in Unilever seemed to involve a number of separate issues (though not raised in the pleadings):

- that the actual investment manager who had been relied on was not that held out at the beginning of the contract, and that the individual manager was important in the management of the contract;

- that the management of the risk of divergence from the benchmark was not up to the highest standards, in other words that the apparent concentrations in the portfolio 
involved a breach of the normal risk management criteria.

The only reported decision involving a failure to invest properly appears to be a UK case, National Westminster Bank case. ${ }^{5}$ In 1986 Miss Nestle inherited from her grandfather who had died in 1922 leaving an estate then worth $\mathcal{E}^{5} 54,000$. National Westminster Bank was the trustee of her grandfather's will, which provided life interests for the widow and children. By 1960, when the widow died, the fund was worth over f105,000, of which 15 per cent was in fixed interest securities and 85 per cent in equities which consisted entirely of bank and insurance shares.

By 1986 the fund was worth

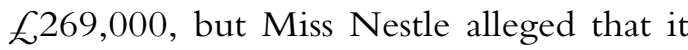
would have been worth more than $f_{1} 1 \mathrm{~m}$ if the bank had managed the trust with proper care, and sued on the grounds that it was in breach of its duty as a prudent trustee by not diversifying the investments in equities between 1922 and 1960 (because it did not understand it had powers to invest in other equities or because it failed to review the investments regularly).

The bank accepted that it had wrongly assumed, without legal advice, that its powers of investment were limited to the actual bank and insurance company shares held by the testator at the date of his death or similar shares. At first instance, Miss Nestle's claim was dismissed; Miss Nestle then appealed to the UK Court of Appeal.

The Court of Appeal held that a failure by a trustee to review trust investments regularly is indeed a breach of trust; but such a breach does not necessarily give rise to a remedy where the beneficiary fails to prove that such a breach causes loss. It is not sufficient for a beneficiary merely to prove loss of a chance that he would have been better off if the portfolio had been diversified; in the absence of such proof, no loss is proved.

Even where the trustee or fund manager is not an effective manager of investments under its control, for any claim to be made a beneficiary must show a breach of trust resulting in loss. A comparison with the composition of the equity shares index is insufficient to prove any loss because that index was calculated by reference to the performance of leading equity shares and the composition of the list changed with companies' fortunes and therefore could not be the criterion for the degree of performance expected of the ordinary prudent trustee.

A trustee, although required to act prudently, incurs no liability for a decision made on wrong grounds or for an untenable reason if it subsequently appeared that there were good grounds for the decision. And even where a decision not to invest in equities is made for an untenable reason, for example where the fund manager or trustee considers it has no power to make an investments in equities then recommended by its stockbrokers, such a decision can be regarded as objectively right on a correct appreciation of the facts.

The measure of damages where a trustee fails to act fairly or impartially in respect of the administration of a trust is fair compensation and not merely the least compensation for the failure to follow the correct policy or the difference between the actual performance and what a prudent trustee would have been likely to have achieved, not merely the least that could have been achieved. In the end, the claim by Miss Nestle was rejected by both the High Court and the Court of Appeal.

It was clear from Nestle, therefore, 
although the claim itself failed, that in principle a fund manager can be liable for breach of a duty of care. A similar claim failed in an Australasian case involving the assets of a pension trust. In Jones $v$ AMP [1995] 07 PBLR, a New Zealand insurance company managed the investments of the defined contribution pension fund for its own staff. The trustee of the scheme was its own trustee company. Following a collapse in the stock market, the value of the benefits linked to the defined contributions also fell. Scheme members complained that the trustee subsidiary of the employer should not have held the assets in a managed fund with the employer, it being a form of prohibited self-investment; and if not self-investment, then have mingled investments with other assets of the employer; not diversified investment managers; not charged fees on the management of the assets, because of the conflict of interest.

The insurer as employer both denied the allegations, and asserted that, regardless of any formal breach of trust, it was entitled to the benefit of relief against liability because it had acted in good faith.

It was held that a trustee has a duty to take advice on exercising any power of investment and to act prudently on that advice; good faith and sincerity are no defences to a breach of that duty. A trustee is not required to accept such advice. A trustee is neither an insurer nor guarantor of the value of a trust's assets.

A trustee is not negligent for making an error of judgment. A trustee's performance is to be judged not by hindsight but by the facts in existence at the time of the occurrence. A trustee is not negligent to retain stock in a period of declining market values. No higher duty of care is imposed on a trustee company with affiliations with a fund manager. The principle that a trustee cannot profit from the management of the trust is to ensure that the trustee's loyalty to serve the interests of the trust, or the beneficiaries of the trust, is not distracted by a personal interest which conflicts with those interests. Quantifying a loss one month after a stockmarket crash, the court held, is not a proper basis for measuring any alleged losses.

With this robust defence of trustees, who arguably have a higher duty of care than a contractor, the defence of Merrill Lynch seemed also robust. In Jones it was held that the employer was not in breach of its fiduciary duty to serve the best interests of the trust or the beneficiaries. Neither the insurer nor its parent profited directly from the investments. It was also held that the investment contract was a life insurance policy for the purposes of the trust deed, because it possessed the essential features of a life insurance policy by providing for benefits in the event of retirement, disability or death of the insured person in return for the payment of premiums. The fact that AMP managed the investment fund and that the payment of the life insurance company's surplus to the insured in the form of a bonus did not prevent the contract being a contract of insurance.

\section{Conclusions}

The Unilever non-case is almost certainly bound to lead to a plethora of seminars and discussion papers; it crystallises some of the leading issues in investment management arrangements both in the UK and the USA. While the parties to the case have argued it relies on very specific facts, the question of whether there is a duty of care, and if so what that duty is, remains to be settled. It is improbable that the first test of that duty in the courts will be brought by trustees of a current trust; certainly in the UK 
the costs are unpredictable, and unlike in the USA follow the cause (so that the loser has to pay both sides' costs), a Beddoe (pre-emptive costs) order is unlikely to be made, and the risk/reward ratio of such litigation is likely to be low. But there are good chances are it will be brought by the independent trustee of a pension scheme affiliated to a sponsoring employee in liquidation and which itself is in deficit and unable to pay the promised or expected benefits. Suing an underperforming asset manager on the grounds of negligence seems an obvious solution to a problem; and finding inadequate systems, or unrigorous risk-management arrangements in an asset manager may not be difficult, especially where the performance has been very poor. The fact that discretionary fund managers are not trackers is the reason that such volatility exists in the first place. Moreover, there is no doubt that benchmarks are missed day after day; someone somewhere will allege that the performance has been so bad that no normal manager would have invested as this manager did. Such a case may not be long in coming; and one judge will soon have to decide just how bad investment performance has to be to amount to negligence.
Meanwhile, asset managers around the world are reviewing their investment management agreements, considering whether their exemption from liability clauses are strong enough, and discussing how much cover they need from their professional indemnity insurers. Trying to exclude liability for negligence in an investment management contract may not, however, be easy, especially following a run of UK case law which holds that such clauses may not be effective where they amount to allowing 'fundamental breach' of the original contract, which is not permitted. And it is not common these days for the UK litigation scene to be ahead of that in the USA; presumably someone somewhere in the USA is preparing to sue an asset manager on just these grounds.

(C) Robin Ellison

\section{References}

1 Much of the story is available on the Financial Times website www.ft.com.

2 Myners, P. (2001) 'Review of Institutional Investment', www.hm-treasury.gov.uk, March.

3 See www.ifma.org.uk.

4 Cripps, E. (2002) 'Unilever goes all active with bonds', Financial Times Mandate, 28th January, (an interview with Wendy Mayall).

5 Nestle v National Westminister Bank [2002] WTLR 795; [2002] 01 PBLR. 